\title{
Growth pattern and yield of NERICA 1 and NERICA 4 rice varieties as a function of split nitrogen application at Tsukuba, East Japan
}

\author{
Workneh Bekere ${ }^{1,}$, Hisashi Urayama ${ }^{2}$, Masaaki Togashi \\ ${ }^{1}$ Ethiopian Institute of Agricultural Research, Jimma Research Center; P.Box 192, Jimma, Ethiopia \\ ${ }^{2}$ Japan International Corporation Agency, Tsukuba International Center; 3-6, Koyadai; Tsukuba, Japan \\ Email address: \\ keneni02@yahoo.com (W. Bekere)
}

\section{To cite this article:}

Workneh Bekere, Hisashi Urayama, Masaaki Togashi. Growth Pattern and Yield of NERICA 1 and NERICA 4 Rice Varieties as a Function of Split Nitrogen Application at Tsukuba, East Japan. Agriculture, Forestry and Fisheries. Vol. 3, No. 1, 2014, pp. 24-29. doi: $10.11648 /$ j.aff.20140301.15

\begin{abstract}
The study was conducted with the aim of investigating the effect of split application of nitrogen on growth and yield of NERICA 1 and NERICA 4 rice varieties at Tsukuba International Center, Japan from April to September 2013 cropping season. The varieties were investigated for establishment, plant height, tiller number, SPAD value, shoot dry matter, panicle dry matter, nitrogen uptake, panicle number, spikelet number, panicle length, ripening ratio, thousand grain weight, harvest index and paddy yield. The result showed that NERICA 1 had significantly greater establishment percentage, shoot dry matter, panicle length and thousand grain weight than NERICA 4, but its leaves were significantly $(\mathrm{p}<0.05)$ less green than the latter after 55 days of sowing. Dividing $80 \mathrm{~kg} \mathrm{~N}^{-1}{ }^{-1}$ into two and applying half rate at sowing as basal and top dressing at panicle initiation gave significantly more green leaves than either at once application of full rate or half rate as basal and half rate top dressing at heading applications from 90-115 days after sowing. However, application of half rate of $80 \mathrm{~kg} \mathrm{~N} \mathrm{ha}^{-1}$ at sowing and heading time produced significantly $(\mathrm{p}<0.05)$ more green leaves than at once and half as basal and at panicle initiation after 115 days of sowing. It also produced significantly longer panicles than the other two modes of $\mathrm{N}$ applications. In all of the evaluated parameters, varieties and split nitrogen applications failed to show significant ( $\mathrm{p}>0.05)$ interaction. Splitting $80 \mathrm{~kg} \mathrm{~N} \mathrm{ha}^{-1}$ in to two and applying half of it at sowing and the remaining half at panicle initiation as well as applying half of it at sowing and the remaining half at heading time increase panicle length compared to applying full rate at once during sowing.
\end{abstract}

Keywords: Growth, NERICA, Nitrogen, Split Application, Yield

\section{Introduction}

Rice is a stable food for more than half of the world population. It is not only a main source of calories but also an important source of income and employment. Despite its considerable importance, yield of the crop is very low especially in case of upland rice as farmers have limited access to production technologies (IRRI, 1986). High yields are indeed possible under upland conditions. Under ideal conditions on experiment stations, yields of 7.0 and $7.2 \mathrm{t} /$ ha have been reported in the Philippines and Peru respectively (Abifarin et al. 1972). It is indicated that a quantity as high as $5.4 \mathrm{t} / \mathrm{ha}$ and $6 \mathrm{t} / \mathrm{ha}$ were also reported in Nigeria and Ethiopia respectively (Seyuom et al., 2011; Abifarin et al. 1972). Appropriate agronomic packages coupled with adequate nutrient supply at an appropriate time play pivotal role in expression of yielding potential of crops. Among these, nitrogen is the most essential nutrient which limits growth and yield. Insufficient and inappropriate nitrogen fertilizer application may account for two thirds of the gap between actual and potential yields (Alagesan and Raja Babu, 2011)

Response of rice varieties to $\mathrm{N}$ is generally recognized, but crop recovery of applied $\mathrm{N}$ is only $50 \%$ due to the losses in several ways. Fertilizer $\mathrm{N}$ use efficiency of rice may be improved through a better timing of application to coincide with the stages of peak requirement of the crop. Various strategies have been developed to harmonize plant $\mathrm{N}$ demand and $\mathrm{N}$ supply from soil and fertilizers. These include proper timing, rate, type and placement of the 
fertilizer (Rahman, et al., 2009; Sathiya and Ramesh, 2009). However, the response of upland rice varieties to split application of nitrogen fertilizer is still controversial. The study was therefore, conducted to investigate the effect of split application of nitrogen fertilizer on growth and yield of NERICA 1 and NERICA 4 rice varieties under upland condition.

\section{Material and Methods}

Field experiment was conducted in Tsukuba International Center, Japan, experimental field from April 2013 to September 2013. The soil of the Center is neutral in reaction with high organic matter (Table 1)

Table 1. Chemical properties of experimental soil

\begin{tabular}{ll}
\hline Properties & Values \\
\hline $\mathrm{pH}(1: 2.5 \mathrm{H} 2 \mathrm{O})$ & 6.3 \\
Organic carbon (\%) & 3.5 \\
Total N (\%) & 0.3 \\
$\mathrm{NH}_{4}-\mathrm{N}(\%)$ & 0.03 \\
Available P (mg kg-1) & 38.0 \\
Exchangeable $\mathrm{K}\left(\mathrm{mg} \mathrm{kg}^{-1}\right)$ & 250.0 \\
Exchangeable Ca $\left(\mathrm{mg} \mathrm{kg}^{-1}\right)$ & 1540.0 \\
Exchangeable $\mathrm{Mg}\left(\mathrm{mg} \mathrm{kg}^{-1}\right)$ & 735.0 \\
\hline
\end{tabular}

Meteorology report of the Center showed that there was deviation of precipitation and temperature of the experimental season from the normal year. In July and August, the former was highly reduced whereas the latter was increased when compared to precipitation and temperature of the normal year of Tsukuba International Center (Fig 1).

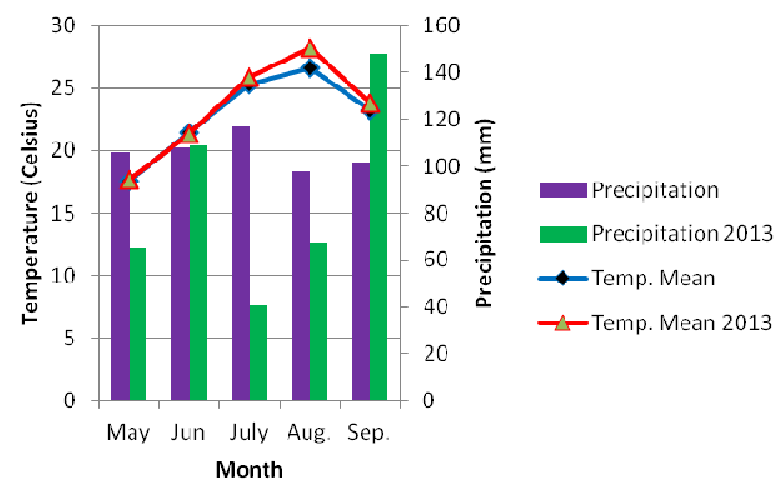

Fig 1. Temperature and precipitation of the experimental season and normal year

The recommended full rate of $\mathrm{N}$ for the area, $80 \mathrm{~kg} \mathrm{~N} \mathrm{ha}^{-1}$, was used for splitting. The experiment consists of three nitrogen split applications. These are application of full rate $\left(80 \mathrm{~kg} \mathrm{~N} \mathrm{ha}^{-1}\right)$ at sowing as basal whereas the second mode was in two splits half of the recommended rate $\left(40 \mathrm{~kg} \mathrm{~N} \mathrm{ha}^{-1}\right)$ as basal at planting and the remaining half $\left(40 \mathrm{~kg} \mathrm{~N} \mathrm{ha}^{-1}\right)$ as top dress at panicle initiation. The third type was also in two splits in which $50 \%$ of the recommended amount (40kg $\mathrm{N} \mathrm{ha}{ }^{-1}$ ) is applied as basal during sowing time but the remaining half rate $\left(40 \mathrm{~kg} \mathrm{~N} \mathrm{ha}^{-1}\right)$ was applied at heading.

NERICA 1 and NERICA 4 varieties were used for the investigation. The three levels of mode of nitrogen application were factorial combined with two rice varieties (3 $\times 2$ 2) making a total of six treatment combinations and conducted in RCB design with three replications. A field of $277.2 \mathrm{~m}^{2}$ was prepared and finally divided in to three blocks and 18 plots with an area of $12 \mathrm{~m}^{2}$. Paths of $1 \mathrm{~m}$ between replications were left for easy management of the experimental field. Before planting, a composite soil sample was taken from the upper $0-0.10 \mathrm{~m}$ of the experimental field and analyzed for selected physical and chemical properties. For all plots, $100 \mathrm{~kg} \mathrm{ha}^{-1} \mathrm{P}_{2} \mathrm{O}_{5}$ and $\mathrm{K}_{2} \mathrm{O}$ were applied for $\mathrm{P}$ and $\mathrm{K}$ sources respectively.

\subsection{Seed Preparation and Sowing}

A seed rate of $40 \mathrm{~kg} \mathrm{ha}^{-1}$ was used for the two varieties. Seeds from these varieties were selected using 1.06 specific gravity of salt water solution. The seeds were then soaked in Benreto-T (Thiuram 20\%-Benomyl 20\% powder) fungicide for 10 minutes to avoid seed borne diseases. They were then dried and coated with KIHIGEN (TMTD 80\%) bird repellent. The seeds were dried and sown in $0.6 \mathrm{~m}$ row spacing by drilling them within a row at about $2-4 \mathrm{~cm}$ depth. On the third day of sowing, pendimethalin 30\% (GOGOSAN) herbicide was applied by $25 \mathrm{~L} \mathrm{ha}^{-1}$ rate for weed control.

\subsection{Investigation Items}

Growth parameters such as SPAD value (chlorophyll content), shoot dry weight, plant height and tiller number were recorded and evaluated (Gomez and Gomez, 1984). Panicle number per square meter, spikelet per panicle, percentage of ripened grains, thousand grain weight, paddy grain yield and harvest index were investigated at maturity as yield components of the rice varieties. Nitrogen uptake of the crops grown in different split and application time was analyzed. Mean separation was made according to Tukey at $5 \%$ probability levels.

\section{Results and Discussions}

\subsection{Emergency Percentage}

Nitrogen application timing did not affect seedling emergency. Similarly, varieties and N split application interaction was not significant. However, emergency of NERICA 1 was significantly $(\mathrm{p}<0.05)$ higher than NERICA 4. This may be related to seed size of the varieties in which more stored food is found for the growing seedling in bigger seeds of the former variety than the latter. It is observed that timing of nitrogen application did not bring any change on emergency percentage of the varieties under investigation 
Table 2. Effect of variety and split nitrogen application on seedling establishment of NERICA rice at TBIC, Japan

\begin{tabular}{cc}
\hline Varieties & Seedling establishment (\%) \\
\hline NERICA 1 & $90 \mathrm{a}$ \\
NERICA 4 & $70 \mathrm{~b}$ \\
HSD (5\%) & 5.6 \\
Significance & $* * *$ \\
N Split & \\
B only & 81.5 \\
$1 / 2(\mathrm{~B}+\mathrm{PI})$ & 79.8 \\
$1 / 2 \mathrm{~B}+\mathrm{HD})$ & 78.0 \\
HSD (5\%) & $\mathbf{8 . 4}$ \\
Significance & $\boldsymbol{n s}$ \\
Variety $X N$ split & $\boldsymbol{n s}$ \\
CV (\%) & $\mathbf{6 . 6 5}$ \\
\hline
\end{tabular}

Means within a column followed by same letter/s are not significantly different at $\mathrm{p}<0.05$.

***: significantly different at 0.001 probability; ns: no significant difference at $\mathrm{p}<0.05$.

B: basal; PI: panicle initiation; HD: heading

\subsection{Plant Height}

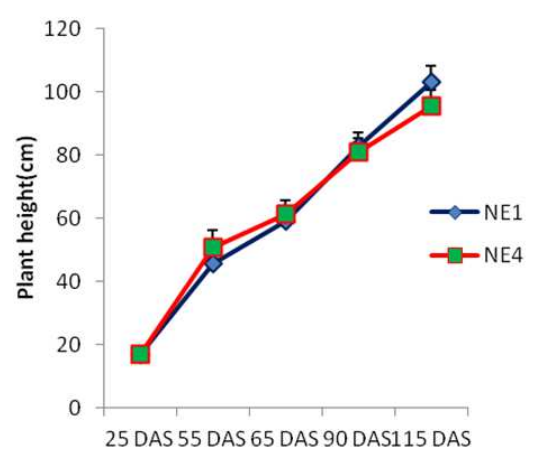

NE1: NERICA 1; NE4: NERICA 4; DAS: Days after sowing

Fig 2. Effect of varieties on plant height at Tsukuba,

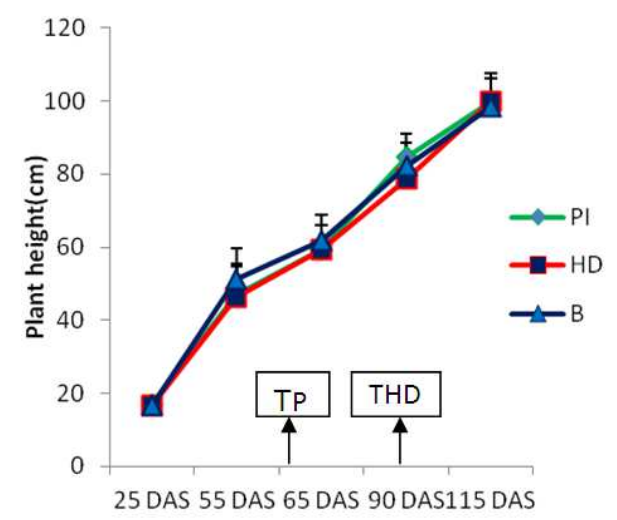

B: basal only; PI: $1 / 2($ B + PI); HD: $1 / 2($ B + HD); TPI: top dressing at panicle initiation; THD: top dressing at heading; PI: panicle initiation HD: heading

Fig 3. Effect of split $N$ application on plant height of NERICA Rice varieties

There was no interaction of rice varieties and timing of mineral $\mathrm{N}$ application. It is revealed that NERICA 1 and NERICA 4 had similar height throughout growth period except at maturity at which the former was significantly taller than the later (Fig 2). Splitting $\mathrm{N}$ application also did not bring any change in height of the crop except at ninety days after sowing when top dressing of $50 \mathrm{~kg} \mathrm{~N}$ ha-1 at panicle initiation resulted in significantly taller plant than basal only application and top dressing at heading (Fig 3).

\subsection{Tiller Number}

Varieties produced almost similar number of tillers throughout the growth period. Timing of $\mathrm{N}$ supplying also had no effect on the number of tillers. This is due to the presence of appreciable amount of nitrogen in experimental soil on which the crop depends when the element is not applied. This finding is against Alagesan and Raja Babu (2011) who reported increase of tiller number of wet seeded rice by split application of $\mathrm{N}$. Interaction effect of the varieties and time of $\mathrm{N}$ application did not have any interaction.

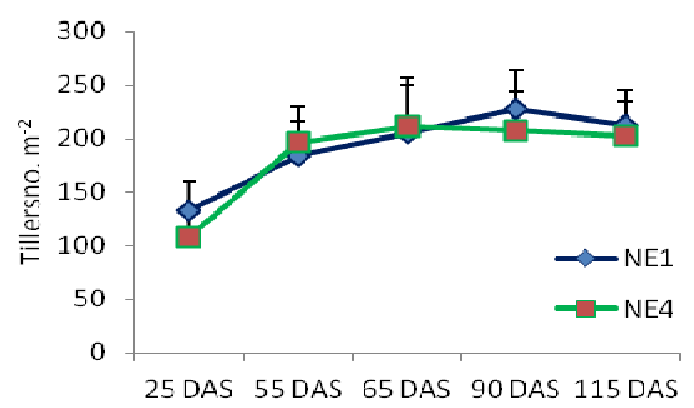

NE1: NERICA 1; NE4: NERICA 4; DAS: Days after sowing

Fig 4. Effect of varieties on tiller no. of NERICA Rice varieties at Tsukuba, Japan

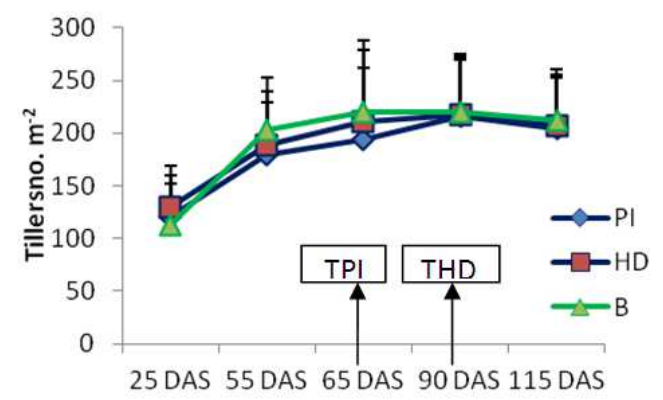

B: basal only; PI: 1/2 (B + PI); HD: 1/2 ( B + HD); TPI: top dressing at panicle initiation; THD: top dressing at heading; PI: panicle initiation HD: heading

Fig 5. Effect of split $N$ application on tiller no. of NERICA rice varieties

\subsection{SPAD Value}

Up to 55 days after sowing, both varieties had similar spade value. However, NERICA 4 had significantly higher SPAD value than NERICA 1 after these days (Table 3). Nitrogen split application also had significant effect on spade value of the varieties. Full rate application at sowing time only resulted in significantly higher value than $50 \% \mathrm{~N}$ top dressing at panicle initiation and heading times up to 55 days after sowing. However, top dressing of $50 \%$ of 
mineral nitrogen at panicle initiation gave higher SPAD value than full rate application at sowing only and $50 \% \mathrm{~N}$ amount top dressing at heading (Table 3). This is attributed to the quick effect of $\mathrm{N}$ applied as top dressings. Generally, interaction effect of the varieties and the timings of $\mathrm{N}$ application was not significant (Table 3).

Table 3. SPAD value of two NERICA rice as affected by varieties and timings of $N$ application

\begin{tabular}{|c|c|c|c|c|c|}
\hline Varieties & 25 DAS & 55 DAS & 65 DAS & 90 DAS & $\begin{array}{l}115 \\
\text { DAS }\end{array}$ \\
\hline NERICA 1 & 34.9 & 40.8 & $42.6 b$ & $43.9 b$ & $40.7 b$ \\
\hline NERICA 4 & 36.5 & 41.6 & $44.0 \mathrm{a}$ & $44.9 \mathrm{a}$ & $42.3 \mathrm{a}$ \\
\hline$H S D \quad 5 \%$ & 1.6 & 1.5 & 1.1 & 0.9 & 1.3 \\
\hline Significance & $n s$ & $n s$ & $*$ & $*$ & $*$ \\
\hline \multicolumn{6}{|l|}{ N split } \\
\hline Basal only & 35.8 & $43.5 \mathrm{a}$ & $45.0 \mathrm{a}$ & $44.1 \mathrm{~b}$ & $38.9 \mathrm{c}$ \\
\hline $1 / 2(B+P I)$ & 36.2 & $40.4 b$ & $42.4 b$ & $45.7 \mathrm{a}$ & $41.6 \mathrm{~b}$ \\
\hline $1 / 2(B+H D)$ & 35.0 & $39.5 \mathrm{~b}$ & $42.5 \mathrm{~b}$ & $43.5 \mathrm{~b}$ & $44.0 \mathrm{a}$ \\
\hline HSD $5 \%$ & 1.9 & 1.9 & 1.4 & 1.1 & 1.9 \\
\hline Significance & $n s$ & $* *$ & $* *$ & $* *$ & $* * *$ \\
\hline $\begin{array}{l}\text { Variety } X N \\
\text { split }\end{array}$ & $n s$ & $n s$ & $n s$ & $n s$ & $n s$ \\
\hline $\mathrm{CV} \%$ & 4.1 & 3.5 & 2.5 & 2.0 & 3.0 \\
\hline
\end{tabular}

Means within a column followed by same letter/s are not significantly different at $\mathrm{p}<0.05$

$*, * *$ and $* * *$ are significantly different at $0.05,0.01$ and 0.001 probability respectively.

B: basal; PI: panicle initiation; HD: heading; ns: no significant difference at $\mathrm{p}<0.05$.

\subsection{Dry Matter Production}

\subsubsection{Shoot Dry Matter and N Uptake at Panicle Initiation}

Table 4. Influence of varieties and split $N$ application on shoot dry matter and nitrogen uptake of NERICA 1 and NERICA

\begin{tabular}{lll}
\hline Treatments & Dry matter (g/plant) & $\mathbf{N}\left(\mathbf{g} / \mathbf{m}^{\mathbf{2}}\right)$ \\
\hline NERICA 1 & 1.1 & 5.8 \\
NERICA 4 & 1.0 & 4.8 \\
HSD (5\%) & 0.3 & 2.2 \\
significance & $n s$ & $n s$ \\
N split & & \\
Basal only & 1.1 & \\
1/2(B + PI) & 1.0 & 6.1 \\
1/2(B + HD) & 0.9 & 4.4 \\
HSD (5\%) & 0.4 & 4.6 \\
significance & $n s$ & 3.4 \\
Variety XN split & $n s$ & $n s$ \\
CV (\%) & 30.4 & $n s$ \\
\hline
\end{tabular}

Means within a column followed by same letter/s are not significantly different at $\mathrm{p}<0.05$.

B: basal; PI: panicle initiation; HD: heading; ns: no significant difference at $\mathrm{p}<0.05$.

The result revealed that there was no significant effect of varieties and split mineral $\mathrm{N}$ application on shoot dry matter and $\mathrm{N}$ accumulation in shoot of the crop. Moreover, interaction effect of the varieties and the $\mathrm{N}$ application time was not significant (Table 4). Song et al. (2013) and Prudente (2008) also reported similar result in which N uptake by rice varies only with $\mathrm{N}$ amount not by split application. Rahman et al. (2013) also reported the need of drainage for $\mathrm{n}$ uptake. This similar nitrogen content in varieties and varieties supplied with nitrogen at different time is due to the higher nitrogen content of the experimental soil.

\subsubsection{Shoot Dry Matter at Maturity}

Shoot dry matter accumulation was affected by rice varieties at maturity in which NERICA 1 produced significantly higher dry matter than NERICA 4 (Fig 6). However, dry matter production of panicles was not significantly influenced by NERICA rice varieties. Split nitrogen application on the other hand, produced similar shoot and panicle dry matter (Fig.8; Fig 9). This report is in agreement with finding of Reddy and Patrick (1980) who reported weak correlation of rice straw and $\mathrm{N}$ fertilizer application.

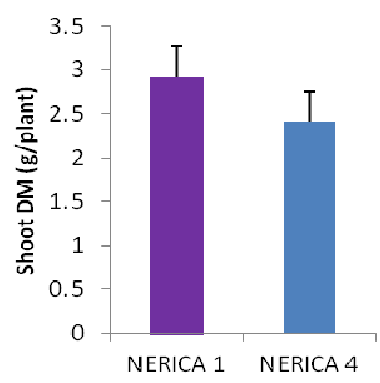

Fig 6. Effect of rice varieties on shoot (leaf + stem) dry matter production at maturity.

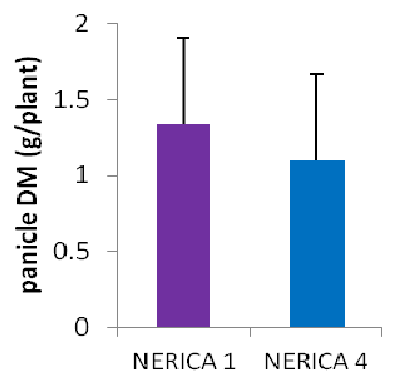

Fig 7. Effect of varieties on panicle dry matter production at maturity

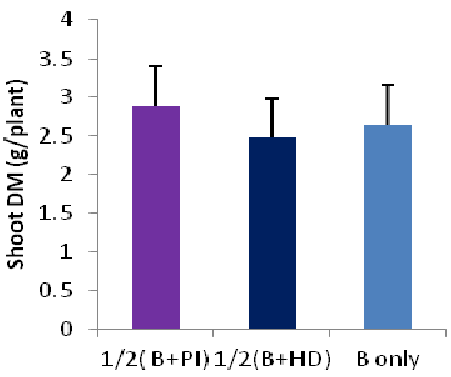

Fig 8. Effect of split $N$ application on shoot dry matter production at maturity. 


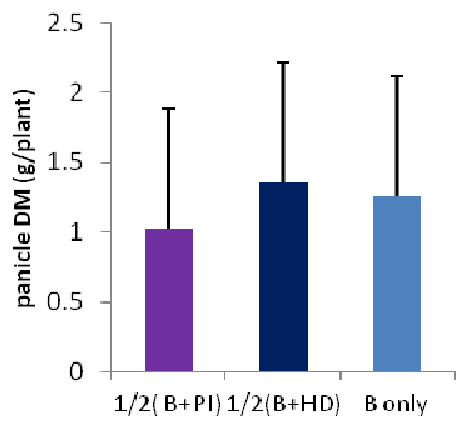

Fig 9. Effect of split $N$ application on panicle dry matter of NERICA rice varieties at maturity.

\subsubsection{Yield and Yield Components}

It is revealed that varieties and timing of $\mathrm{N}$ application did not affect panicle number and ripening percentage (Table 5). However, effects of varieties and $\mathrm{N}$ application timing was observed on panicle length where NERICA 1 produced significantly $(\mathrm{P}<0.05)$ longer panicle than NERICA 4. Similarly, top dressing of $50 \% \mathrm{~N}$ amount at heading time gave significantly $(\mathrm{P}<0.05)$ longer panicles than full rate application at sowing only (Table 5). The result also showed that NERICA 1 produced more spikelet than NERICA 4 but split $\mathrm{N}$ application gave almost the same spikelet number. Neither rice varieties nor splitting and split $\mathrm{N}$ application had an effect on ripening ration, harvest index and paddy yield. This result is against Fagera, (2007) who reported that nitrogen timing has an effect on rice yield components under controlled green house condition. Split N application did not affect thousand grain weight. On the other hand, NERICA 1 gave significantly $(\mathrm{P}<0.05)$ higher thousand grain weight $(26.3 \mathrm{~g})$ than NERICA 4 (24.5g).

Table 5. Effect of varieties, split and timing of $N$ application on panicle no., panicle length, spikelet no., ripening ratio, thousand grain weight, paddy yield and harvest index at Tsukuba

\begin{tabular}{|c|c|c|c|c|c|c|c|c|}
\hline Variety & $\begin{array}{l}\text { Panicle no. } \\
/ \mathbf{m}^{2}\end{array}$ & $\begin{array}{l}\text { Panicle } \\
(\mathrm{cm})\end{array}$ & length & $\begin{array}{l}\text { Spikelet } \\
\text { no./panicle }\end{array}$ & $\begin{array}{l}\text { Ripening ratio } \\
(\%)\end{array}$ & 1000 grain weight $(g)$ & Paddy yield (t/ha) & HI \\
\hline NERICA 1 & 181.8 & $25.5 \mathrm{a}$ & & 90.5 & 68.5 & $26.3 \mathrm{a}$ & 1.9 & 0.51 \\
\hline NERICA 4 & 178.7 & $23.5 b$ & & 76.3 & 73.3 & $24.5 b$ & 1.5 & 0.48 \\
\hline$H S D(5 \%)$ & 27.2 & 1.6 & & 15.2 & 9.1 & 1.5 & 0.7 & 0.13 \\
\hline Significance & $n s$ & * & & $n s$ & $n s$ & $*$ & $n s$ & $n s$ \\
\hline \multicolumn{9}{|l|}{$\mathrm{N}$ split } \\
\hline Basal only & 182.8 & $23.7 \mathrm{~b}$ & & 88.0 & 73.1 & 25.1 & 1.9 & 0.53 \\
\hline $1 / 2(B+P I)$ & 178.7 & $24.1 \mathrm{ab}$ & & 79.4 & 67.3 & 25.3 & 1.6 & 0.42 \\
\hline $1 / 2(B+H D)$ & 179.2 & $25.7 \mathrm{a}$ & & 82.7 & 72.2 & 25.9 & 1.7 & 0.52 \\
\hline$H S D(5 \%)$ & 40.8 & 2.0 & & 22.9 & 13.7 & 2.2 & 1.1 & 0.21 \\
\hline Significance & $n s$ & * & & $n s$ & $n s$ & $n s$ & $n s$ & $n s$ \\
\hline Variety $X N$ split & $n s$ & $n s$ & & $n s$ & $n s$ & $n s$ & $n s$ & $n s$ \\
\hline $\mathrm{CV} \%$ & 14.3 & 6.4 & & 17.4 & 12.2 & 5.5 & 39.0 & 26.1 \\
\hline
\end{tabular}

Means within a column followed with same letter/s are not significantly different at $\mathrm{P}<0.05$.

*: significant difference at $\mathrm{p}<0.05$; ns: no significant difference at $\mathrm{p}<0.05$.

B: basal; PI: panicle initiation; HD: heading

\section{Conclusion}

NERICA 1 and NERICA 4 rice varieties have similar growth rates and give comparable and paddy yield. Splitting $80 \mathrm{~kg} \mathrm{~N} \mathrm{ha}^{-1}$ in to two and applying half of it at sowing and the remaining half at panicle initiation as well as applying half of it at sowing and the remaining half at heading time increase panicle length compared to applying full rate at once during sowing. Further investigation should be made under more uniform and lower soil $\mathrm{N}$ content.

\section{Acknowledgment}

The author would like to express his gratitude to Japan International Corporation Agency for financial and material support for the experiment. Technical advisors of Tsukuba
International Center (JICA) are also appreciated for their technical guidance.

\section{References}

[1] Abifarin. A. O. R. Chabrolin, M. Jacquot, R. Marie, and J. C. Moomaw, 1972. Upland rice improvement in West Africa. Pages 625-635: In International Rice Research Institute, Rice breeding. Los Baiios, Philippines.

[2] Alagesan and Raja Babu, 2011. Impact of Different Nitrogen Levels and Time of Application on Grain Yield and Yield Attributes of Wet Seeded Rice. Inter. J. Food, Agri. Vet. Sci. 1(1): 1-5.

[3] Fageria, N. K., 2010. Optimal nitrogen Fertilization Timing for Upland rice. $19^{\text {th }}$ World Congress of Soil Science, Soil Solutions for a Changing World, 1 - 6 August 2010, Brisbane. 
[4] Gomez, K.A and A.A. Gomez, 1984. Statistical Procedures for Agricultural Research. $2^{\text {nd }}$ edition. John Wiley and Sons, Inc. pp. 84-118.

[5] International Rice Research Institute, 1986. UPLAND RICE: A Global Perspective. (Eds. Gupta and Toole). Los Baños, Laguna, Philippines.

[6] Rahman M.M., T. Amano and T. Shiraiwa, 2009. Nitrogen use efficiency and recovery from $\mathrm{N}$ fertilizer under ricebased cropping systems. Aus. J. of Crop Sci., 3(6):336-351

[7] Prudente J. A., Gilbert C. Sigua, Manoch, Kongchum and Alfredo D. Prudente, 2008. Improving Yield and Nutrient Uptake Potentials of Japonica and Indica Rice Varieties with
Nitrogen Fertilization. World Journal of Agricultural Sciences 4 (4): 427-434.

[8] Reddy, K. R. and Patrick W. H., 1980. Uptake of Fertilizer Nitrogen and Soil Nitrogen by Rice using ${ }^{15} \mathrm{~N}$ Labeled Nitrogen Fertilizer. Plant and soil, 57:378-381.

[9] Rahman, S. M., K. Kakuda, Y. Sasaki and H. Ando, 2013. Effect of Mid-season Drainage (MSD) on Growth and yield of Rice in North East Japan. Am. J. Plant Nutr. Fert. Technol.,3(2): 33-42.

[10] Sathiya and Ramesh, 2009. Effect of Split Application of Nitrogen on Growth and Yield of Aerobic Rice. Asian J. Exp. Sci,: 23 (1), 303-306. 